\title{
Effect of Unpuddled Transplanting on the Growth and Yield of Dry Season Rice (Oryza sativa L.) in High Barind Tract
}

\author{
A. K. M. S. Islam ${ }^{1}$, M. M. Hossain ${ }^{2}$ and M. A. Saleque ${ }^{1}$ \\ ${ }^{1}$ Bangladesh Rice Research Institute, Gazipur, Bangladesh; \\ ${ }^{2}$ Bangladesh Agricultural University, Mymensingh, Bangladesh \\ *Corresponding author and Email: akmsaifulislam68@gmail.com
}

Received: 09 March $2014 \quad$ Accepted: 13 December 2014

\begin{abstract}
Conservation tillage technology not only protects natural resources but also provides some economic leverage. The present investigation evaluated two puddle tillages (i) conventional tillage (CT) and (ii) single pass wet tillage (SPWT) and two unpuddled tillages(iii) strip tillage(ST) and (iv) bed planting (BP) to establish rice in the High Barind Tract, Godagari, Rajshahi during aus 2010 and boro 2011 season. The CT option incurred higher cost compared to other tillage treatments due to more fuel and labour used in land preparation. Minimum tillage (SPWT, ST and BP) saved about 30-54\% fuel consumption and 40-49\% labour requirement compared to CT in land preparation. Labour did not face much difficulty to transplant seedling in unpuddled fields. However, unpuddled establishment required more labor for weeding compared to puddle one. Bed planting in aus gave significantly lower grain yield than other establishment methods. However, in boro season, all the tested tillage methods produced similar yield. In both seasons, CT showed the highest input costs due to more number of tillage passes and fuel requirement in land preparation. As a consequence, SPWT, ST and BP appeared to be more profitable than $\mathrm{CT}$ both in aus and boro rice.
\end{abstract}

Keywords: Strip tillage, bed planting, fuel consumption, yield, cost

\section{Introduction}

Transplanting rice (Oryza sativa L.) seedlings in puddled soil is a common practice of lowland rice production in the tropics and subtropics of Asia (Cassman and Pingali, 1995). Farmers typically prepare land by two passes of dry tillage followed by exposure to sun for a few days and then inundation of the field, ploughing and harrowing with standing water. This tillage practice is laborious, time consuming and capital intensive process. Ploughing of puddled soil after rice results in the formation of large clods, having high breaking strength (Sharma and Bhagat, 1993) and very large amounts of energy and time are consumed in producing fine seed beds. Puddling destroys soil aggregates, breaks capillary pores, and disperses the soils leading to increased bulk density of surface layers (Gupta et al., 2003). It helps to control weeds and facilitate easy transplanting. Puddling to a greater extent creates soil physical condition detrimental to the following crop in rice based cropping system (Hobbs and Morris, 1996). Puddling makes land preparation difficult for the following wheat or other winter crops, resulting in cloddy soil structure, loss of soil moisture, delayed planting and inadequate seed-soil contact (Sharma et al., 1995). 
Excessive wetness in puddled rice soil can delay the planting of the following wheat and result in yield reductions of $35-40 \mathrm{~kg} \mathrm{ha}^{-1}$ per day by a delay in planting after November 20 (Randhawa et al., 1981 and Hobbs, 1987). Puddling should preferably be avoided as it is an unfavorable practice for the succeeding upland crops. Minimum tillage shows an advantage over puddling in a clay loam soil for maintaining physical condition and saving field preparation time (Brown and Quantrill, 1973). Sharma et al. (1988) reported that rice grown after minimum tillage produced yields similar to that under conventional puddling with minimised expenses on field preparation. Haque (2009) evaluated the unpuddled transplanting of rice on bed, strip and single pass shallow tillage practices and found similar yield compared to conventional puddling with additional benefits in fuel and water savings. Islam et al. (2012) reported that in aman season, bed planting and strip tillage under unpuddled condition saved fuel and water usage by $31-76 \%$ and $25-26 \%$ compared to conventional tillage, respectively. Considerable research work has been done on puddle transplanting, but there is very limited data available on unpuddled rice transplanting. Therefore, the present study was conducted to examine the effect of unpuddled transplanting on growth and yield of rice in High Barind Tract.

\section{Materials and Methods}

The experiment was conducted in the farmer's field at Godagari of Rajshahi district during aus (May-August) 2010 and boro (December-May) 2011 season. In the High Barind Tract (HBT) grey terrace soils are predominant (Brammer, 1996). These soils are mostly silty clay surface horizons. Climatic (rainfall and thermal condition) data were collected from the nearest weather station and are presented in Figure 1.

The treatments were: in puddled condition (i) conventional puddling (CT) (ii) single pass wet tillage (SPWT); and in unpuddled condition (iii) strip tillage (ST) and (iv) bed planting (BP). The treatments were arranged in a randomized complete block (RCB) design with three replications. In land preparation, CT consisted of 2 passes primary tillage by $2 \mathrm{WT}$ and exposed to sun for two days followed by inundating whole plot and puddling by $2 \mathrm{WT}$ with 2 passes to complete land preparation. In SPWT, one pass tillage by 2 WT after inundating the field. ST and BP were done by Versatile Multi-crop Planter (VMP) in single pass operation before inundating the field. Land was inundated one day before transplanting operation for making the land soft to transplant seedling in ST and BP. In $\mathrm{BP}$, the width of bed and furrow were 35 and 20 $\mathrm{cm}$, respectively.

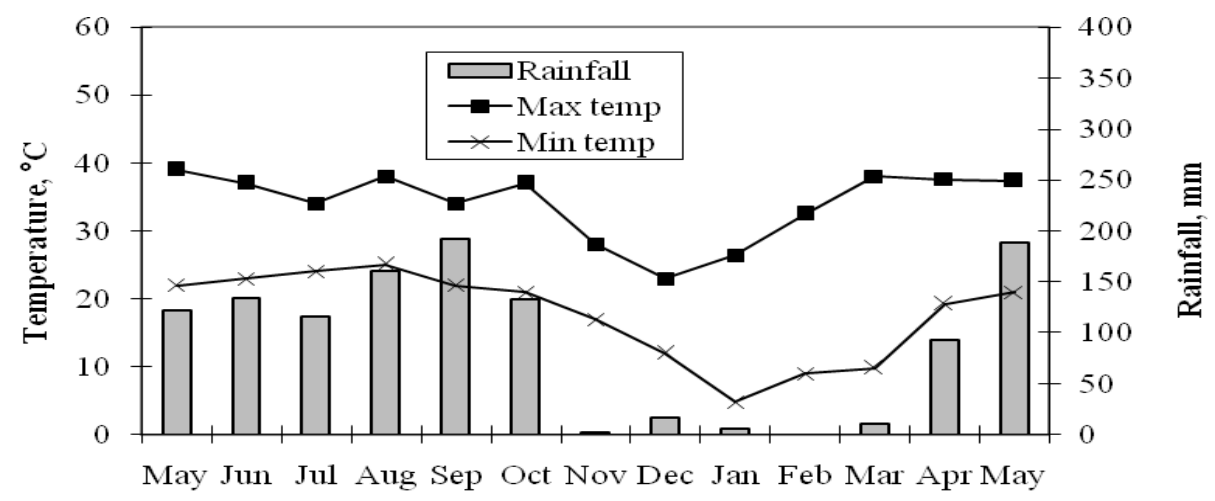

Month

Figure 1: Monthly temperature and rainfall distribution pattern in Godagari, Rajshahi during 2010-11 
In aus season, local variety Parija was sown on 11 May, 2010 and transplanted on 15 June 2010 whereas, in boro season BRRI dhan 28 was sown on 5 December, 2010 and transplanted on 26 January 2010. The seedling spacing for CT, BP and SPWT was $25 \times 15 \mathrm{~cm}$ and $20 \times 15 \mathrm{~cm}$ for ST. Fuel consumption was measured by filling the fuel tank twice, before and after each operation. In aus season, fertilizers were applied at $175,67,133$ and $56 \mathrm{~kg} \mathrm{ha}^{-1}$ as urea, muriate of potash (MP), triple super phosphate (TSP) and gypsum, respectively. In boro season, fertilizers were applied at 217, 100, 178, 7.5 and $83 \mathrm{~kg} \mathrm{ha}^{-1}$ as urea, muriate of potash (MP), triple super phosphate (TSP), zinc sulphate and gypsum, respectively. The entire amount of triple super phosphate, muriate of potash, gypsum and zinc sulphate were broadcasted and incorporated into the soil at final land preparation. Urea was top dressed in three equal installments.

Crops were harvested on 28 August, 2010 and 07 May 2011 in aus and boro season, respectively. Grain yield was recorded from pre-selected 10 $\mathrm{m}^{2}$ area and was adjusted to $14 \%$ moisture content. Panicle number in each unit area was counted to determine the panicle number per $\mathrm{m}^{2}$. Border areas of all sides of the plot were excluded from samples to avoid edge effects.

A simple economic analysis was done based on total production. Production cost included rental charge of the land and input cost. Price of the produce was collected from the local markets to compute total production cost, gross return, gross margin and benefit-cost ratio. Statistical analysis as a one way analysis of variance was done according to Gomez and Gomez (1984). Data were analysed by using statistical software Mstat-C. Means were compared with least significant difference (LSD) test.

\section{Results and Discussion}

\subsection{Fuel consumption}

Tillage treatments showed significant effect on fuel consumption in land preparation. SPWT and ST saved the highest amount of (51-54\%) fuel, whereas BP saved only $30 \%$ inland preparation compared to CT (Table 1).

\subsection{Labour requirement in land preparation, transplanting and weeding}

Tillage treatments showed significant effect on labour requirement for land preparation in aus and boro season (Table 2). CT had the highest labour requirement and ST had the lowest labour requirement for land preparation. Minimum tillage saved (40-49\%) labour compared to CT in land preparation. Tillage treatment shad no significant effect on labour requirement between transplanting of seedlings in puddled and unpuddled condition in two seasons. Tillage treatments significantly affected the weed infestation in boro season. Weeding time was the highest in ST followed by BP, SPWT and CT.

\subsection{Cost of land preparation, transplanting and weeding}

Cost of land preparation, transplanting and weeding as affected by tillage options is shown in Table 3. Tillage treatment showed significant effect on cost of land preparation. Land preparation cost was the highest in CT followed by BP, ST and SPWT. The land preparation cost under minimum tillage decreased up to $34-49 \%$ compared to conventional puddling. Tillage treatments had no significant effect on transplanting cost in puddled and unpuddled conditions. Tillage treatments significantly affected the weeding cost. Weeding cost was the highest in ST followed by BP, SPWT and CT, respectively. Weeding cost increased as tillage passes decreased.

\subsection{Tiller production and grain yield}

At maturity stage, plant population and number of effective tillers per square meter did not vary significantly among tillage treatments in both seasons (Table 4). However, SPWT produced about 22 and 30\% more tillers over CT under puddled condition in the Aus and boro seasons, respectively. Tillage options showed significant effect on grain yield in unpuddled transplanting of aus season rice whereas, there was insignificant effect in boro season. 
Table 1. Fuel consumption $\left(\mathrm{L} \mathrm{ha}^{-1}\right)$ under different tillage system

\begin{tabular}{lccc}
\hline & Treatment & \multicolumn{3}{c}{ Fuel consumption $\left(1 \mathrm{ha}^{-1}\right)$} \\
\cline { 2 - 4 } & Aus & Boro & Mean \\
\hline Puddled & 33 & 41 & 37 \\
CT & 14 & 21 & 18 \\
SPWT & & & \\
Unpuddled & 18 & 15 & 17 \\
ST & 20 & 31 & 26 \\
BP & 6.9 & 4.1 & \\
\hline LSD & 16.05 & 7.6 & \\
CV $(\%)$ & & & \\
\hline
\end{tabular}

N.B. Values are the means of three replicates, $\mathrm{CT}=$ Conventional tillage, SPWT $=$ Single pass wet tillage, $\mathrm{ST}=$ Strip tillage, $\mathrm{BP}=$ Bed planting

Table 2. Labour requirement (man-hr ha ${ }^{-1}$ ) in land preparation, transplanting and weeding for different tillage systems

\begin{tabular}{lcccccccc}
\hline Treatment & \multicolumn{3}{c}{ Land preparation } & \multicolumn{3}{c}{ Transplanting } & \multicolumn{2}{c}{ Weeding } \\
\cline { 2 - 8 } & Aus & Boro & Mean & Aus & Boro & Mean & Aus & Boro \\
\hline Puddled & & & & & & & & \\
CT & 47 & 43 & 45 & 106 & 79 & 93 & Pretilachlor & 116 \\
SPWT & 23 & 30 & 27 & 111 & 75 & 93 & $\begin{array}{l}\text { applied, } \\
\text { no weeds }\end{array}$ & 125 \\
Unpuddled & & & & & & & grown & 345 \\
ST & 24 & 22 & 23 & 109 & 93 & 101 & 262 \\
BP & 30 & 23 & 27 & 110 & 92 & 101 & & 39.3 \\
\hline LSD 0.05 & 3.8 & 7.7 & & NS & NS & & & 9.3 \\
CV $(\%)$ & 6.2 & 4.6 & & 11.2 & 16.7 & & & \\
\hline
\end{tabular}

N.B. Values are the means of three replicates, $\mathrm{CT}=$ Conventional tillage, SPWT $=$ Single pass wet tillage, $\mathrm{ST}=$ Strip tillage, $\mathrm{BP}=$ Bed planting

Table 3. Cost $\left(\mathrm{Tk} \mathrm{ha}^{-1}\right)$ of land preparation, transplanting and weeding

\begin{tabular}{lcccccccc}
\hline Treatment & \multicolumn{3}{c}{ Land preparation } & \multicolumn{3}{c}{ Transplanting } & \multicolumn{2}{c}{ Weeding } \\
\cline { 2 - 9 } & Aus & Boro & Mean & Aus & Boro & Mean & Aus & Boro \\
\hline Puddled & & & & & & & & \\
CT & 4858 & 4494 & 4676 & 2640 & 1977 & 2309 & Pretilachlor & 2894 \\
SPWT & 2246 & 2410 & 2328 & 2778 & 1877 & 2328 & applied, & 3135 \\
Unpuddled & & & & & & & no weeds & \\
ST & 2592 & 2218 & 2405 & 2723 & 2317 & 2520 & grown & 8616 \\
BP & 3121 & 3004 & 3063 & 2739 & 2305 & 2522 & & 6559 \\
\hline LSD $_{0.05}$ & 635.9 & 179.6 & & NS & NS & & & 982.2 \\
CV, \% & 9.93 & 2.97 & & 11.15 & 16.72 & & & 9.27 \\
\hline
\end{tabular}

N.B. Values are the means of three replicates, $C T=$ Conventional tillage, SPWT $=$ Single pass wet tillage, $\mathrm{ST}=$ Strip tillage, $\mathrm{BP}=\mathrm{Bed}$ planting 
Table 4. Yield and yield attributes of unpuddled transplanted rice in aus and boro seasons

\begin{tabular}{|c|c|c|c|c|c|c|}
\hline \multirow[t]{2}{*}{ Treatment } & \multicolumn{2}{|c|}{$\begin{array}{c}\text { Tiller } \\
\left(\text { no. } \mathrm{m}^{-2}\right)\end{array}$} & \multicolumn{2}{|c|}{$\begin{array}{l}\text { Effectivetillers } \\
\left(\text { no. } \mathrm{m}^{-2}\right)\end{array}$} & \multicolumn{2}{|c|}{$\begin{array}{c}\text { Grain yield } \\
\left(\mathrm{t} \mathrm{ha}^{-1}\right)\end{array}$} \\
\hline & Aus & Boro & Aus & Boro & $A u s$ & Boro \\
\hline \multicolumn{7}{|l|}{ Puddled } \\
\hline $\mathrm{CT}$ & 408 & 440 & 362 & 348 & 4.03 & 4.10 \\
\hline SPWT & 477 & 541 & 443 & 455 & 4.46 & 3.97 \\
\hline \multicolumn{7}{|l|}{ Unpuddled } \\
\hline $\mathrm{ST}$ & 412 & 462 & 368 & 371 & 4.02 & 4.14 \\
\hline BP & 394 & 482 & 359 & 391 & 3.34 & 4.36 \\
\hline $\mathrm{LSD}_{0.05}$ & $\mathrm{NS}$ & NS & $\mathrm{NS}$ & NS & 0.72 & NS \\
\hline $\mathrm{CV}(\%)$ & 12.8 & 17.5 & 13.8 & 21.0 & 9.1 & 5.7 \\
\hline
\end{tabular}

N.B. Values are the means of three replicates, $\mathrm{CT}=$ Conventional tillage, SPWT $=$ Single pass wet tillage, $\mathrm{ST}=$ Strip tillage, $\mathrm{BP}=$ Bed planting

Table 5. Economic productivity of rice under different tillage systems

\begin{tabular}{|c|c|c|c|c|c|c|c|}
\hline \multirow{2}{*}{$\begin{array}{l}\text { Tillage } \\
\text { options }\end{array}$} & \multicolumn{2}{|c|}{ Aus } & \multicolumn{2}{|c|}{ Boro } & \multicolumn{3}{|c|}{ BCR } \\
\hline & $\begin{array}{l}\text { Input cost } \\
\left(\mathrm{Tk} . \mathrm{ha}^{-1}\right)\end{array}$ & $\begin{array}{c}\text { Gross } \\
\text { return } \\
\left(\mathrm{Tk}^{-1} \mathrm{ha}^{-1}\right)\end{array}$ & $\begin{array}{l}\text { Input cost } \\
\left(\mathrm{Tk} . \mathrm{ha}^{-1}\right)\end{array}$ & $\begin{array}{c}\text { Gross } \\
\text { return } \\
\left(\mathrm{Tk}^{-1} \mathrm{ha}^{-1}\right)\end{array}$ & Aus & Boro & Mean \\
\hline \multicolumn{8}{|l|}{ Puddled } \\
\hline CT & 50,590 & 72,960 & 50,050 & 72,855 & 1.44 & 1.46 & 1.45 \\
\hline SPWT & 49,020 & 80,770 & 48,520 & 70,643 & 1.65 & 1.46 & 1.56 \\
\hline Unpuddled & & & & & & & \\
\hline $\mathrm{ST}$ & 49,630 & 72,840 & 48,370 & 75,293 & 1.47 & 1.56 & 1.52 \\
\hline $\mathrm{BP}$ & 49,630 & 61,400 & 48,630 & 78,034 & 1.24 & 1.61 & 1.43 \\
\hline
\end{tabular}

N.B. Values are the means of three replicates, $\mathrm{CT}=$ Conventional tillage, SPWT $=$ Single pass wet tillage, $\mathrm{ST}=$ Strip tillage, $\mathrm{BP}=$ Bed planting

\subsection{Economic analysis}

Table 5 shows economic productivity of unpuddled transplanting of rice as influenced by tillage options. In both season, CT showed the highest input costs due to more number of tillage passes and fuel consumption for land preparation. Averaged over two season, BCR was the highest in SPWT (1.56) followed by ST (1.52), CT (1.45) and BP (1.44), respectively.

Minimum tillage reduced fuel and labour requirement in land preparation due to limited number of tillage operations. Labour did not encounter any difficulty to transplant seedlings in unpuddled field due to soil softness as water was applied before transplanting and soil was silty clay. The soil type may interact with the length of wetting in order to facilitate unpuddled transplanting. Weeding was not needed in aus season. This might be due to short duration variety and crop canopy suppressing the weeds. Weed infestation was less throughout the growing period in all the tillage plots. In boro season, crop canopy could not suppress the weeds due to long duration variety. Weeding cost was higher in unpuddled than puddled plot. This can be attributed to dry zone on the top of bed and in the strip tillage that aided weed emergence. Applying non-selective herbicide (glyphosate) before land preparation might be helpful to control weed in unpuddled plot as in 
the case of wheat (Om et al., 2006), direct seeded rice (Subramanian et al., 2006) and transplanted rice (Natarajan and Kuppuswarmy, 1999).

BP showed the lowest grain yield. It was due to the lower number of plant population and effective tillers. This lower number of effective tillers was attributed to poor establishment of the crop. Grain yield was statistically similar among CT, SPWT, ST and BP in boro season. Sharma et al. (2005) reported similar yield in transplanted rice for one pass in wet soil and conventional puddling. All tillage treatments provided similar grain yields of rice as was reported with many studies on minimum tillage even though most of the research was on rainfed crops (Sharma et al., 2011) rather than transplanted rice. The present experiment showed that grain yield in minimum tillage puddled and unpuddled transplanting of rice was similar to CT indicating that tillage intensity can be reduced to establish transplanted rice without sacrificing yield. However, these results contradict with the suggestion of Baker and Saxton (2007).

Input costs included fuel, labour, machine rental charge and other expenses from seedbed preparation to harvest operations including transportation. Same amount of seed, fertilizer, pesticides and irrigation water was applied in all the plots. The number of passes and operation of costs in terms of fuel and time consumption were different among tillage options. In both seasons, CT showed the highest input costs due to more number of tillage passes and fuel requirement in land preparation. In both seasons, minimum tillage decreased input cost. This was coincided with Raper et al., (1994) who stated that minimum tillage decreased the input costs for labor, fuel, tractors, and other equipment. In aus season, gross return was the highest in SPWT due to the highest grain yield. In boro season, tillage options did not show significant effect on gross return due to similar grain yield. The benefit cost ratio was higher in SPWT because of the higher grain yield and lower input costs. BP showed the lowest BCR due to the fact that input cost was higher as well as gross margin was lower compared to other tillage treatment.

\section{Conclusions}

Tillage intensity can be reduced to establish transplanted rice without sacrificing yield. Single pass wet tillage could be promoted in the traditional puddled rice cultivation areas in High Barind Tract. Transplanting rice in unpuddled strip and bed was also promising in aus and boro seasons for conducting the research work.

\section{Acknowledgement}

This study was a part of the $\mathrm{PhD}$ research of the senior author. The authors acknowledge the funding support from NATP- Phase 1, Bangladesh Agricultural Research Council.

\section{References}

Baker, C. J. and Saxton, K. E. 2007. No-tillage Seeding in Conservation Agriculture, 2nd edn. CAB International and FAO. Food and Agriculture Organization of the United Nations (FAO), Rome, Italy. 326 pp.

Brammer, H. 1996. The geography of the soils of Bangladesh. University Press Limited, Dhaka.

Brown, I. A. and Quantrill, R. A. 1973. The role of minimum tillage in rice with particular reference to Japan. Outlook on Agriculture, 7: 179-183.

Cassman, K. G. and Pingali, P. L. 1995. Extrapolating trends from long-term experiments to farmers' fields: the case of irrigated rice systems in Asia. In: Barnett, V., Payne, R., Steiner, R. (Eds.), Agricultural Sustainability: Economic, Environmental and Statistical Considerations. John Wiley \& Sons, New York, 63-84 pp.

Gomez, K. A. and Gomez, A. A. 1984. Statistical Procedures in Agricultural 
Research, New York, Chichester, etc.: Wiley, 2nd edition, $680 \mathrm{pp}$.

Gupta, R. K., Hobbs, P. R., Harrington. L. And Ladha, J. K. 2003. Rice-wheat system: problem analysis and strategic entry points, addressing resource conservation issues in rice-wheat systems of South Asia: A resource book, Rice-Wheat Consortium for the Indo-Gangetic PlainsInternational Maize and Wheat Improvement Centre, New Delhi. 16-23 pp.

Haque, M. E. 2009. On-farm evaluation of unpuddled transplanting on bed, strip, and single pass shallow tillage for boro rice cultivation. 2nd Annual Meeting of ACIAR Funded Rice-Maize Project. BRAC Center, Dhaka, Bangladesh. 3-4 October, 2009. International Rice Research Institute (IRRI), and International Maize and Wheat Improvement Center (CIMMYT), Dhaka, Bangladesh.

Hobbs, P. and Morris, M. 1996.Meeting South Asia's Future food requirement from ricewheat cropping systems: Issues facing researchers in the post-green revolution era. NRG paper 96-01 Mexico, D.F., CIMMYT.

Hobbs, P. R. 1987. A perspective on research needs for the rice-wheat rotation. In:Klatt AR (Ed.) Wheat Production Constraints in Tropical Environment. Proceedings, 197$211 \mathrm{pp}$.

Islam, A. K. M. S., Hossain, M. M., Saleque. M. A., Rahman, M. A., Karmakar, B. And Haque, M. E. 2012: Effect of minimum tillage on soil properties, crop growth and yield of aman rice in drought prone northwest Bangladesh. Bangladesh Agronomy Journal, 15(1):43-51.

Natarajan, S. and Kuppuswamy, G. 1999. Effect of weed management in rice (Oryza sativa) and its carryover effect on succeeding blackgram (Phaseolus mungo) crop. Indian Journal of Agronomy, 44:477-482.
Om, H., Nandal, D. P., Dhiman, S. D. and Ram, M. 2006. Weed control in wheat (Triticum aestivum) sown by zero-tillage. Indian Journal of Agronomy, 51:199-201.

Randhawa, A. S., Dillon, S. S. and Singh, D. 1981. Productivity of wheat varieties as influenced by the time of sowing. Journal of Research Punjab Agricultural University, 18:227-233.

Raper, R. L., Reeves, E. W., Burt, E. C. And Torbert, H. A. 1994.Conservation tillage and traffic effects on soil conditions. Trans. ASAE 37:763-768.

Sharma, P., Abrol, V. and Sharma, R. K. 2011.Impact of tillage and mulch management on economics, energy requirement and crop performance in maize-wheat rotation in rainfed subhumid Inceptisols, India. European Journal of Agronomy, 34:46-51.

Sharma, P. Tripathi, R. P. and Singh, S. 2005. Tillage effects on soil physical properties and performance of rice-wheat-cropping system under shallow water table conditions of tarai, northern India. European Journal of Agronomy, 23(4):327-335.

Sharma, P. K., Bhagat, R. M. 1993.Puddling and compaction effects on water permeability of texturally different soils. Journal of the Indian Society of Soil Science, 41:1-6.

Sharma, P. K., De Datta, S. K. and Redulla, C. A. 1988. Tillage effects on soil physical properties and wet land rice yield. Agronomy Journal, 80:34-39.

Sharma, P. K., Ingram, K. T. andHarnpichitvitaya, D. 1995. Subsoil compaction to improve water use efficiency and yields of rainfed lowland rice in coarse-textured soils. Soil and Tillage Research, 36:33-44.

Subramanian, E., James, M. G. and Balasubramanian, R. 2006. Effect of integrated weed-management practices on growth and yield of wet-seeded rice (Oryza sativa) and their residual effect on succeeding pulse crop. Indian Journal of Agronomy, 51:93-96. 